\title{
PERUBAHAN TUTUPAN LAHAN DAN PENGARUHNYA TERHADAP POLA PERSEBARAN SUHU DI KOTA GORONTALO
}

\author{
Mohammad Duka ${ }^{\mathrm{a}, \mathrm{b}}$, Firyane Lihawa ${ }^{\mathrm{a}}$, Sukirman Rahim ${ }^{\mathrm{a}}$ \\ ${ }^{a}$ Program Studi Kependudukan dan Lingkungan Hidup, Program Pasca Sarjana Universitas Negeri Gorontalo, Jalan \\ Jenderal Sudirman No. 6 Kota Gorontalo, Provinsi Gorontalo, Indonesia 96128 \\ ${ }^{b}$ Dinas Lingkungan Hidup dan Kehutanan Provinsi Gorontalo, Indonesia
}

\section{INFO ARTIKEL}

\section{Status artikel:}

Diterima: 30 September 2019

Disetujui: 23 November 2019

Tersedia online: 25 Januari 2020

\section{Kata kunci:}

Gorontalo City; Land Cover; Temperature Distribution

\section{Penulis korespondensi:}

Fitryane Lihawa

Program Studi Kependudukan dan

Lingkungan Hidup Program Pasca

Sarjana Universitas Negeri Gorontalo

Email : fitryane.lihawa@ung.ac.id

\begin{abstract}
Gorontalo City is one of the regions in Gorontalo Province. Urban development and population growth, causing pressure on land use patterns. Changes in land use are carried out to meet the community's needs for infrastructure. At present, development in Gorontalo City is still ongoing. The increase in temperature is expected to continue and can trigger heat island. This is very important to be studied for the Gorontalo City development planning that is more environmentally friendly. This study aims to analyze the heat island phenomenon through the relationship of the spatial distribution of surface temperature with various types of land cover and vegetation characteristics. The object of this research is the Gorontalo City area on Landsat path-row 121- 65 satellite imagery media. The research material is the wavelength of visible light, near-infrared and moderate infrared and thermal wavelengths on satellite imagery of Landsat TM and OLI TIRS. The results showed an increase in temperature in Gorontalo City since 1990, 2003, and 2017. The correlation between surface temperature and land cover is negative. The value of the correlation coefficient $(\mathrm{r})$ in 1990 was -0.41 . The correlation coefficient (r) in 2003 was -0.448 . The correlation coefficient (r) in 2017 is -0.402 . Changes in surface temperature in Gorontalo City are influenced by changes in the land cover which is marked by the similarity of patterns of changes in surface temperature distribution with patterns of land cover changes.
\end{abstract}

Copyright (C) 2020 JGEOSREV-UNG This open-access article is distributed under a Creative Commons Attribution (CC-BY) 4.0 International license

\section{Pendahuluan}

Lajunya pembangunan di masa sekarang ini menjadi indikator kemajuan suatu daerah sehingga pemerintah berupaya mendukung pembangunan disemua aspek. Di sisi lain pembangunan berdampak pada perubahan kualitas lingkungan. Perubahan tutupan lahan dari yang bervegetasi menjadi ruang terbuka atau material buatan seperti beton dan aspal dapat mengakibatkan perubahan kualitas lingkungan. Banyakya material buatan, dapat meningkatkan radiasi matahari terperangkap sehingga suhu disekitarnya semakin tinggi. Tutupan vegetasi mampu menurunkan suhu melalui proses evaporasi dan transpirasi (evapotanspirasi) serta peneduhan. Pada peristiwa evaporasi, akar tanaman menyerap air dan kemudian air tersebut dibawa ke daun. Selanjutnya pada proses transpirasi terjadi konversi air menjadi gas. Evapotanspirasi dapat mendinginkan udara disekitarnya karena terdapat penyerapan panas saat terjadi evaporasi. Vegetasi menjadi salah satu aspek yang penting untuk dipertimbangkan pada perencanaan kota terkait isu-isu penurunan kualitas lingkungan meliputi tanah, air, udara dan cuaca kota (Fawzi, 2013).

Pola suatu daerah memiliki suhu yang jauh lebih tinggi bila dibandingkan dengan suhu sekitarnya disebut dengan fenomena heat island (US Environmental Protection Agency, 2012). Perubahan unsur iklim yang terjadi adalah suhu, kecepatan angin, radiasi dan awan. Dari empat unsur tersebut yang dapat dirasakan langsung oleh makhluk hidup adalah perubahan suhu. Dengan adanya peningkatan suhu 
udara akan mengurangi kenyamanan. Kejadian ini banyak terjadi di daerah perkotaan dan pinggiran kota yang mengalami banyak perkembangan jika dibandingkan dengan lingkungan pedesaan yang terpencil. Fenomena tersebut dikenal dengan urban heat island. Pulau panas dapat disebabkan oleh beberapa faktor yaitu bahan permukaan, variasi bentuk dan orientasi sebuah kota dan aktivitas manusia (Kong et al., 2014; Fawzi, 2013)

Kota Gorontalo merupakan salah satu wilayah dari Provinsi Gorontalo. Kota Gorontalo merupakan salah satu kota yang sedang mengalami dinamika pembangunan yang pesat karena adanya pembangunan infrastruktur. Secara teknis hal tersebut telah menarik minat investor untuk membangun usaha di Kota Gorontalo (BAPPEDA Kota Gorontalo, 2010). Dengan lajunya pembangunan di Kota Gorontalo, menyebabkan terjadi perubahan tutupan lahan. Tatura (2010) menjelaskan bahwa terjadi perubahan tutupan lahan di Kota Gorontalo. Pada Tahun 2000, luas lahan pemukiman adalah $1166 \mathrm{Ha}$ meningkat menjadi $1608 \mathrm{Ha}$. Perubahan tutupan lahan tersebut memicu terjadinya peningkatan suhu di Kota Gorontalo. Secara umum, suhu udara di Kota Gorontalo rata-rata pada siang hari $32{ }^{\circ} \mathrm{C}$, sedangkan pada malam hari $23^{\circ} \mathrm{C}$. Kondisi ini menunjukkan suhu di Kota Gorontalo relatif tinggi. Saat ini pembangunan di wilayah utara Kota Gorontalo masih terus berlangsung. Peningkatan suhu diperkirakan akan terus terjadi dan dapat memicu terjadinya heat island. Pembangunan infrastruktur dan fasilitas dalam menunjang kegiatan perekonomian tidak dapat dihindarkan. Perencanaan tata ruang wilayah di Kota Gorontalo diharapkan mampu menciptakan lingkungan yang berkelanjutan, salah satunya melalui perencanaan ruang terbuka hijau.

Berdasarkan kondisi tersebut, maka penting untuk mengkaji perubahan suhu di Kota Gorontalo. Tujuan penelitian ini adalah menganalisis pola distribusi suhu permukaan, trend peningkatan suhu permukaan dan hubungan antara tipe penutupan lahan dengan suhu permukaan di Kota Gorontalo.

\section{Metode}

\subsection{Lokasi Penelitian}

Penelitian dilaksanakan di Kota Gorontalo. Luas wilayah Kota Gorontalo adalah 6699.8 ha atau $0.65 \%$ dari luas Provinsi Gorontalo. Kota Gorontalo terdiri dari 9 kecamatan dan 50 kelurahan. Secara

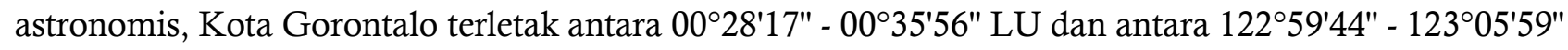
BT. Peta lokasi penelitian ditunjukkan pada Gambar 1.

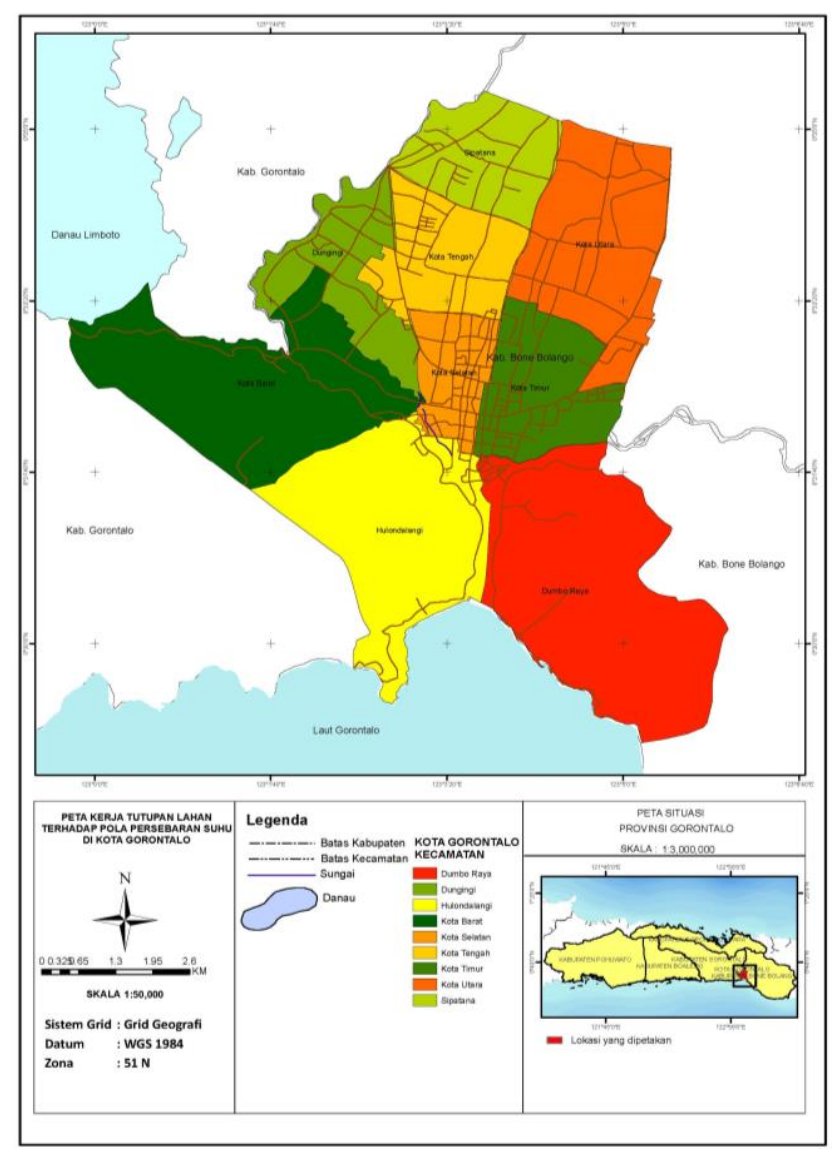

Gambar 1. Peta lokasi penelitian 


\subsection{Metode Penelitian}

Pendekatan dalam penelitian ini adalah pendekatan kuantitatif dan kemudian dianalisis secara deskriptif. Pendekatan kuantitatif digunakan untuk menginterpretasikan data tekstual dan data gambar yang dihasilkan dari proses pengumpulan dan pengolahan data suhu permukaan. Variabel dalam penelitian ini adalah perubahan tutupan lahan dan suhu permukaan.

Objek penelitian ini adalah wilayah Kota Gorontalo pada media citra satelit Landsat path-row 121-65. Bahan yang digunakan adalah panjang gelombang sinar tampak, inframerah dekat dan inframerah sedang serta panjang gelombang thermal pada Citra satelit Landsat TM dan OLI TIRS. Data citra satelit Landsat belum dapat memberikan informasi yang dibutuhkan terkait dengan penelitian ini sehingga membutuhkan proses lebih lanjut untuk memperoleh data melalui proses klasifikasi citra. Proses klasifikasi berdasarkan tekniknya dibedakan atas klasifikasi manual/kualitatif dan klasifikasi kuantitatif. Pada klasifikasi kualitatif, pengelompokkan piksel ke dalam suatu kelas dilakukan oleh interpreter secara manual berdasarkan elemen-elemen dasar yang mencakup warna, bentuk, ukuran, pola, tekstur, bayangan, lokasi dan asosiasi. Klasifikasi secara kualitatif lebih dikenal dengan analisis visual atau interpretasi citra. Mengenali objek merupakan kunci keberhasilan dalam interpretasi untuk mendapatkan informasi. Pada klasifikasi secara kuantitatif pengelompokkan dilakukan secara otomatis oleh komputer berdasarkan nilai kecerahan (digital number/DN) dari contoh yang diambil sebagai area contoh (Jaya, 2006). Dalam penelitian ini dilakukan klasifikasi secara kualitatif.

Selain kegiatan klasifikasi dilakukan konversi data untuk memperoleh data suhu dengan melakukan analisis suhu permukaan/land surface temperature (LST) dengan menggunakan panjang gelombang thermal pada citra Landsat. Data yang dihasilkan dari proses klasifikasi dan konversi berupa data kuantitatif dan data kualitatif. Data kuantitatif yang dihasilkan yaitu data distribusi suhu permukaan dan tutupan lahan. Data kualitatif yang dihasilkan berupa visualisasi atau gambaran sebaran suhu permukaan, kerapatan vegetasi serta jenis tutupan lahan. Pengumpulan data lain dilakukan melalui studi literatur dan survey dari berbagai instansi terkait. Data-data tersebut menjadi bahan yang siap dianalisis sesuai dengan tujuan penelitian.

\subsection{Analisis Data}

Tahap awal analisis, dilakukan perbaikan terhadap data citra satelit yaitu berupa koreksi radiometrik dan koreksi geometrik. Perbaikan radiometrik dilakukan dengan proses penajaman kontras untuk interpretasi citra. Koreksi geometrik dilakukan dengan proses memberikan koordinat peta pada citra sesuai dengan sistem proyeksi yang digunakan. Untuk memperoleh nilai suhu permukaan dilakukan konversi nilai digital pada panjang gelombang thermal menjadi data suhu.

\subsubsection{Konversi data thermal untuk perolehan data suhu permukaan}

1. Konversi Digital Number (DN) menjadi spectral Radiance $\left(\mathrm{L}_{\lambda}\right)$

a. Citra landsat TM

$\mathrm{L}_{\lambda}=$ Grescale $*$ Qcal + Brescale

Persemaan tersebut merupakan penyederhanaan dari:

$\mathrm{L}_{\lambda}=\frac{\mathrm{L}_{\max }-\mathrm{L}_{\text {min }}}{\mathrm{QCal}_{\max }-\mathrm{QCal}_{\min }} \mathrm{x}\left(\mathrm{QCal}-\mathrm{QCal}_{\text {min }}\right)+\mathrm{L}_{\text {min }}$

dimana : $\mathrm{L}_{\lambda}$ adalah radiasi spektral; $\mathrm{Qcal}$ adalah digital number pada panjang gelombang thermal; $\mathrm{L}_{\min }$ adalah radiasi spektral pada skala $\mathrm{Qcal}_{\min } ; \mathrm{L}_{\max }$ adalah radiasi spektral pada skala $\mathrm{Qcal}_{\max } ; \mathrm{Qcal}_{\max }$ adalah nilai maksimum terkuantifikasi dari pixel terkalibrasi; Qcal ${ }_{\min }$ : nilai minimum terkuantifikasi dari pixel terkalibrasi (Lillesand \& Kiefer, 2000).

b. Citra Landsat OLI TIRS

$\mathrm{L} \lambda=\mathrm{Ml} \mathrm{Qcal}+\mathrm{Al}$

dimana: $\mathrm{L}_{\lambda}$ adalah radiasi spektral; ML adalah radiance mult band (diambil dari header file 0.0003342); QCal adalah digital number band thermal; AL adalah radiance add band (diambil dari header file 0.10000) (Lillesand \& Kiefer, 2000). 
Tabel 1. Nilai Konstanta kalibrasi dari band thermal

\begin{tabular}{llll}
\hline No & Satelit & $\mathrm{K}_{1}\left(\mathrm{~W} /\left(\mathrm{m}^{2^{*}}\right.\right.$ ster $\left.^{*} \mu \mathrm{m}\right)$ & $\mathrm{K}_{2}$ (Kelvin) \\
\hline 1 & Landsat TM & 607.76 & 1260.56 \\
2 & Landsat OLI TIRS & 774.89 & 1321.08 \\
& & 480.89 & 1201.14 \\
\hline
\end{tabular}

Sumber : Header file pada landsat yang di gunakan

2. Konversi spectral radiance $\left(\mathrm{L}_{\lambda}\right)$ menjadi temperatur

$$
\mathrm{T}=\frac{\mathrm{K}_{2}}{\operatorname{Ln}\left(\mathrm{x}=\frac{\mathrm{K}_{1}}{\mathrm{~L}_{\lambda}}+1\right)}
$$

dimana: $\mathrm{T}$ adalah suhu efektif $(\mathrm{K}) ; \mathrm{K}_{2}$ adalah konstanta kalibrasi 2 (Tabel 1); $\mathrm{K}_{1}$ adalah konstanta kalibrasi 1 (Tabel 1); $\mathrm{L}_{\lambda}$ adalah radiasi spektral.

\subsubsection{Klasifikasi kuantitatif untuk memperoleh data tutupan lahan}

Klasifikasi kualitatif atau analisis visual dalam konteks multispektral dapat diartikan sebagai suatu proses pengelompokkan pixel yang dilakukan oleh interpreter ke dalam kelas-kelas yang ditetapkan berdasarkan nilai kecerahan maupun warna dari pixel tersebut. Identifikasi objek-objek di permukaan bumi yang tampak pada citra dengan cara mengenalinya atas dasar karakteristik spasial, spektral dan temporal. Elemen spasial dapat meliputi bentuk, ukuran, orientasi dan tekstur seperti jalan, sungai, garis pantai. Elemen temporal dapat meliputi perubahan penutupan lahan (musim, bencana alam, pertumbuhan, dan sebagainya) sedangkan elemen spektral digunakan berdasarkan pengetahuan mengenai teori rekflektansi pada penginderaan jauh (Jaya, 2006).

Penafsiran citra satelit Landsat dilakukan dengan cara deliniasi di layar komputer (on screen digitizing) menggunakan perangkat lunak pengolah citra dan sistem informasi geografis. Dalam melakukan interpretasi citra, untuk mengenali suatu objek digunakan 8 unsur interpretasi yaitu :

1. Rona/warna merupakan elemen interpretasi utama. Rona adalah gradasi kecerahan relative objek pada citra, sedangkan warna adalah perbedaan gradasi warna pada citra.

2. Tekstur merupakan perbedaan tingkat kekasaran objek yang diamati.

3. Pola adalah susunan spasial objek yang dapat dibedakan secara visual, biasanya berwujud pengulangan rona/warna atau tekstur sama yang membentuk pola tertentu.

4. Bentuk adalah kenampakan secara umum, struktur atau bagan objek di lapangan.

5. Bayangan membantu identifikasi objek, misalnya awan, pohon runcing, tajuk sedikit pada lahan terbuka dan semak berukuran tinggi.

6. Ukuran adalah fungsi skala ukuran relatif dapat digunakan untuk mengidentifikasi objek dengan membandingkannya dengan objek lain.

7. Asosiasi digunakan bila beberapa objek berdekatan secara erat, masing-masing objek membantu keberadaan objek yang lain.

8. Situs, menjelaskan tentang posisi muka bumi dari citra yang diamati dalam kaitannya dengan kenampakan disekitarnya.

Skema klasifikasi penggunaan lahan terdiri atas hutan lahan kering primer, pemukiman, pertanian lahan kering, pertanian lahan kering campur semak, sawah, semak belukar, rawa dan tubuh air. Setelah melakukan kegiatan interpretasi citra, dilakukan pengecekan lapangan (ground check). Pengecekan lapangan dilakukan dengan tujuan untuk mengetahui kondisi lapangan atau penutupan lahannya. Pengecekan lapangan tidak dilakukan secara menyeluruh melainkan hanya pada beberapa tempat yang dianggap mewakili masing-masing kelas klasifikasi penutupan lahan. Pengecekan lahan dilakukan untuk penunjang dalam intrepretasi data citra satelit. Hal ini bertujuan untuk memverifikasi data citra dengan kenampakan sebenarnya di bumi. Hasil pengecekan lapangan dijadikan acuan untuk membuat klasifikasi citra yang lebih tepat.

\subsubsection{Indeks vegetasi}

Indeks vegetasi adalah suatu indeks yang dibentuk menggunakan operasi sederhana yaitu pengurangan dan rasio antara saluran inframerah dekat (NIR) dengan saluran merah (RED). Transformasi indeks vegetasi menggunakan NDVI (Normalized Difference Index Vegetation). Indeks vegetasi dengan pendekatan ini menghasilkan nilai yang berkisar antara -1 dan +1 . Tutupan vegetasi lebat cenderung mempunyai nilai NDVI mendekati +1 , lahan kosong umunya mempunyai nilai mendekati nol. Formula dari indeks vegetasi adalah (Jaya, 2006): 
NDVI $=\frac{\text { NIR }- \text { RED }}{\text { NIR }+ \text { RED }}$

dimana: NDVI adalah normalized difference index vegetation; NIR adalah radiasi inframerah dekat dari piksel; RED adalah radiasi cahaya merah dari piksel.

\subsubsection{Analisis hubungan data suhu permukaan, tutupan lahan dan indeks vegetasi}

Hubungan antara suhu permukaan dan tutupan lahan diperoleh dari nilai rata-rata permukaan di setiap tutupan lahan. Sedangkan hubungan fungsional suhu permukaan dan indeks vegetasi dinyatakan dalam bentuk $\mathrm{y}=\mathrm{f}(\mathrm{x})$. Variasi $\mathrm{Y}$ dalam fungsi tersebut dipengaruhi oleh variabel $\mathrm{x}$. Analisis yang dilakukan merupakan analisis data statistik berupa regresi linier sederhana untuk melihat pola hubungan yang terjadi, seberapa besar hubungan yang ada.

Unit contoh yang dianalisis merupakan nilai pixel dari setiap kelas indeks vegetasi (NDVI) yang dihasilkan yaitu berupa nilai suhu permukaan dan nilai indeks vegetasi. Pemilihan unit contoh untuk setiap nilai piksel dilakukan secara random sampling. Jumlah contoh (n) dalam penelitian yang bersifat korelasional sampel minimum yang dapat digunakan adalah 30 unit.

\section{Hasil dan Pembahasan}

\subsection{Tutupan Lahan Kota Gorontalo}

Luas tutupan lahan di Kota Gorontalo pada tahun 1990 sebesar 6699.89 Ha dengan luasan tutupan terbesar adalah sawah dan hutan lahan kering sekunder dengan masing-masing luas sebesar $2471.60 \mathrm{Ha}$ dan $1873.98 \mathrm{Ha}$. Luas pertanian lahan kering campur semak sebesar 990.47 Ha. Lahan pemukiman luasnya 870.25 Ha. Pertanian lahan kering luasnya sebesar 870.25 Ha, semak/belukar luasnya 124.54 $\mathrm{Ha}$ dan tubuh air luasnya $16.96 \mathrm{Ha}$. Tipe tutupan lahan dengan luas terkecil adalah semak belukar rawa dengan luas 5.25 Ha. Pada tahun 2003 dan tahun 2017, terjadi perubahan luasan tutupan lahan. Perubahan yang siginifikan terjadi pada luas hutan lahan kering sekunder dan pemukiman. Luas hutan pada tahun 2003 sebesar 1814.77 Ha menurun hingga 86.14 Ha di tahun 2017. Luas lahan pemukiman pada tahun 2003 sebesar 896.89 Ha meningkat menjadi 2426.99 Ha pada tahun 2017 (Tabel 2). Peta penutupan lahan di Kota Gorontalo ditunjukkan pada Gambar 2.

Perubahan luasan yang terjadi tidak selalu disebabkan oleh adanya konversi lahan dari hutan atau kebun campuran, tetapi juga dipengaruhi oleh pola tanam yang berubah-ubah. Luasan yang tidak tetap namun relatif berkurang dari tahun ke tahun adalah luasan pada penutupan lahan hutan, walaupun secara tepat tidak dapat memperkirakan perubahan luasan yang terjadi karena adanya tutupan awan di sekitar kawasan. Beberapa wilayah berhutan di daerah pegunungan dan sekitarnya pada wilayah tropis seringkali menjadi wilayah yang tertutup awan pada data penginderaan jauh optis. Keberadaan awan menyebabkan panjang gelombang tidak sampai ke objek/permukaan bumi tetapi langsung dipantulkan oleh awan tersebut sehingga data yang terekam berupa awan yang berwarna keputihan dan permukaan bumi terhalang.

Luas perubahan tutupan lahan di Kota Gorontalo banyak disebabkan karena semakin bertambahnya penduduk yang memerlukan lahan untuk tempat tinggal sehingga banyak lahan yang digunakan untuk permukiman. Pertambahan jumlah penduduk merupakan faktor utama dalam mendorong peningkatan lahan kawasan terbangun (Nurhayati, 2016). Berdasarkan klasifikasi, lahan terbangun meliputi

Tabel 2. Luas tutupan lahan di Kota Gorontalo kualitatif/analisis visual data citra landsat

\begin{tabular}{llll}
\hline \multirow{2}{*}{ Tipe tutupan lahan } & \multicolumn{3}{l}{ Luas $(\mathrm{Ha})$} \\
\cline { 2 - 4 } & Tahun 1990 & Tahun 2003 & Tahun 2017 \\
\hline Hutan lahan kering sekunder & 1873.98 & 1814.77 & 86.14 \\
Pemukiman & 870.25 & 896.89 & 2426.99 \\
Pertambangan & - & - & 28.32 \\
Pertanian lahan kering & 270.04 & 270.04 & 431.12 \\
Pertanian lahan kering campur semak & 990.47 & 984.40 & 703.79 \\
Sawah & 2471.60 & 2592.96 & 1181.44 \\
Semak/belukar & 124.54 & 41.81 & 1694.11 \\
Semak belukar rawa & 5.25 & 5.25 & 30.80 \\
Tubuh Air & 93.76 & 93.76 & 117.17 \\
\hline Total & 6699.89 & 6699.89 & 6699.89 \\
\hline
\end{tabular}

Sumber : hasil interpretasi Citra Landsat tahun 1990, 2003, dan 2017 
(a)

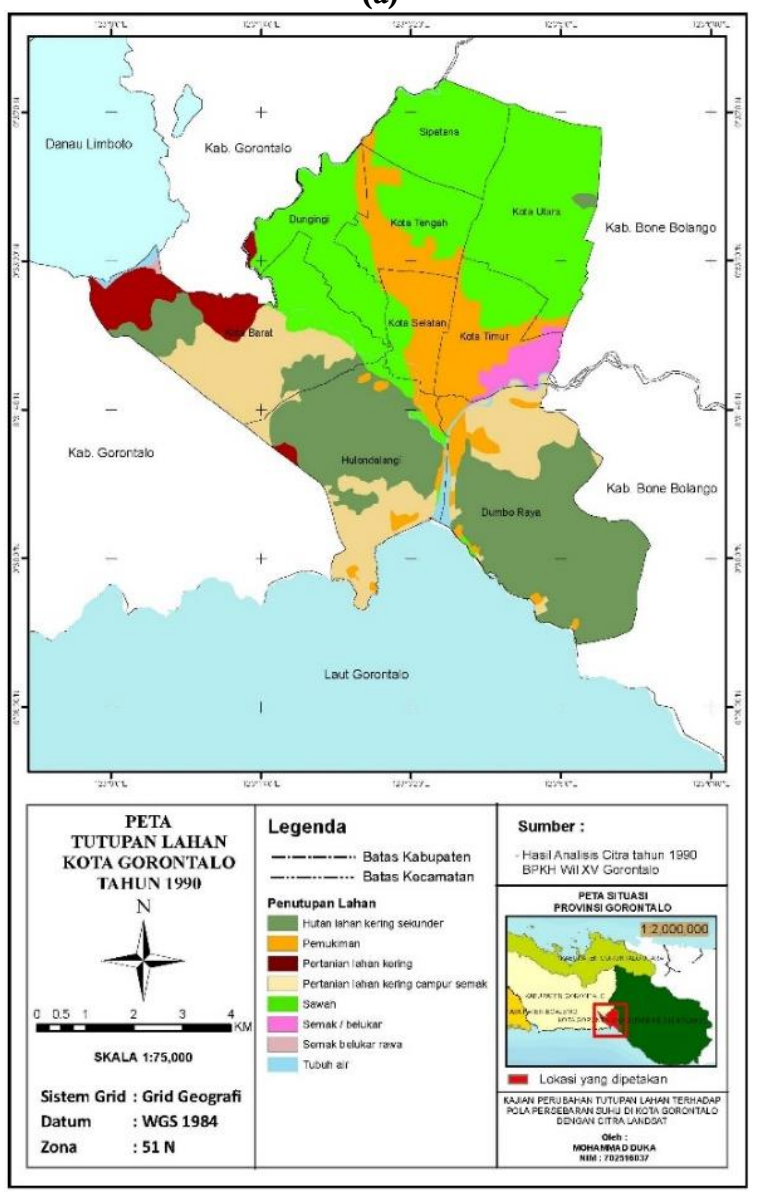

(c)

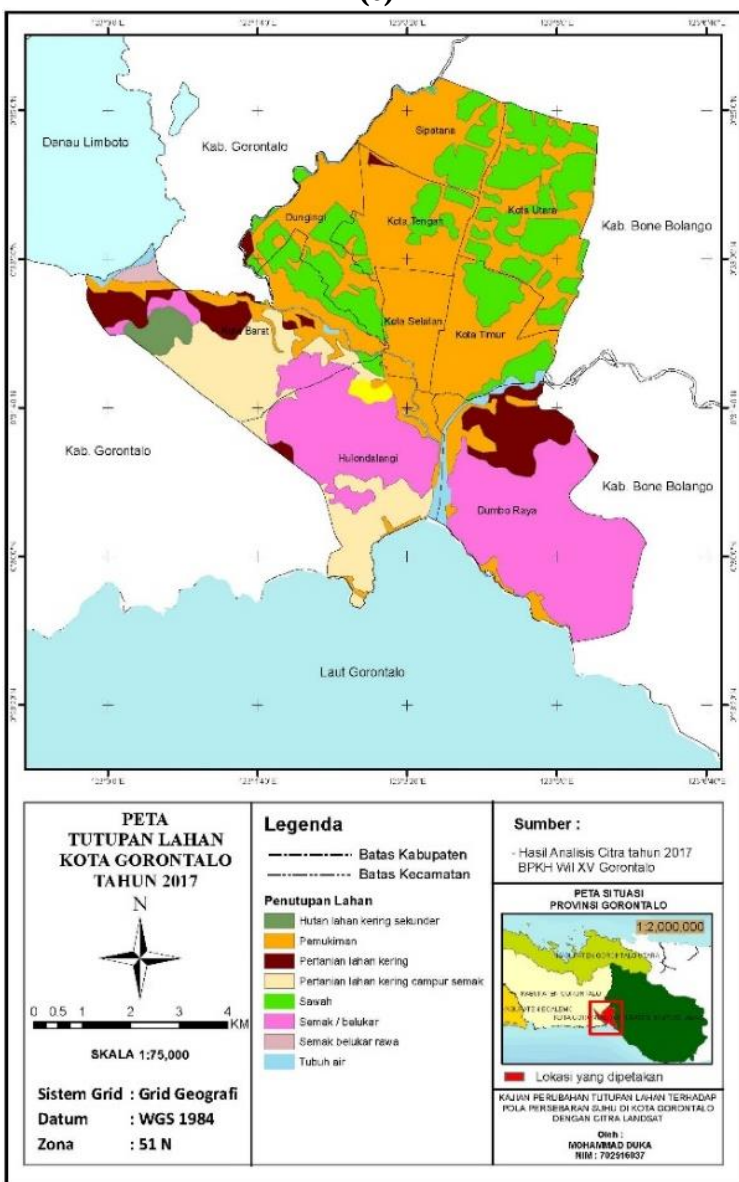

(b)

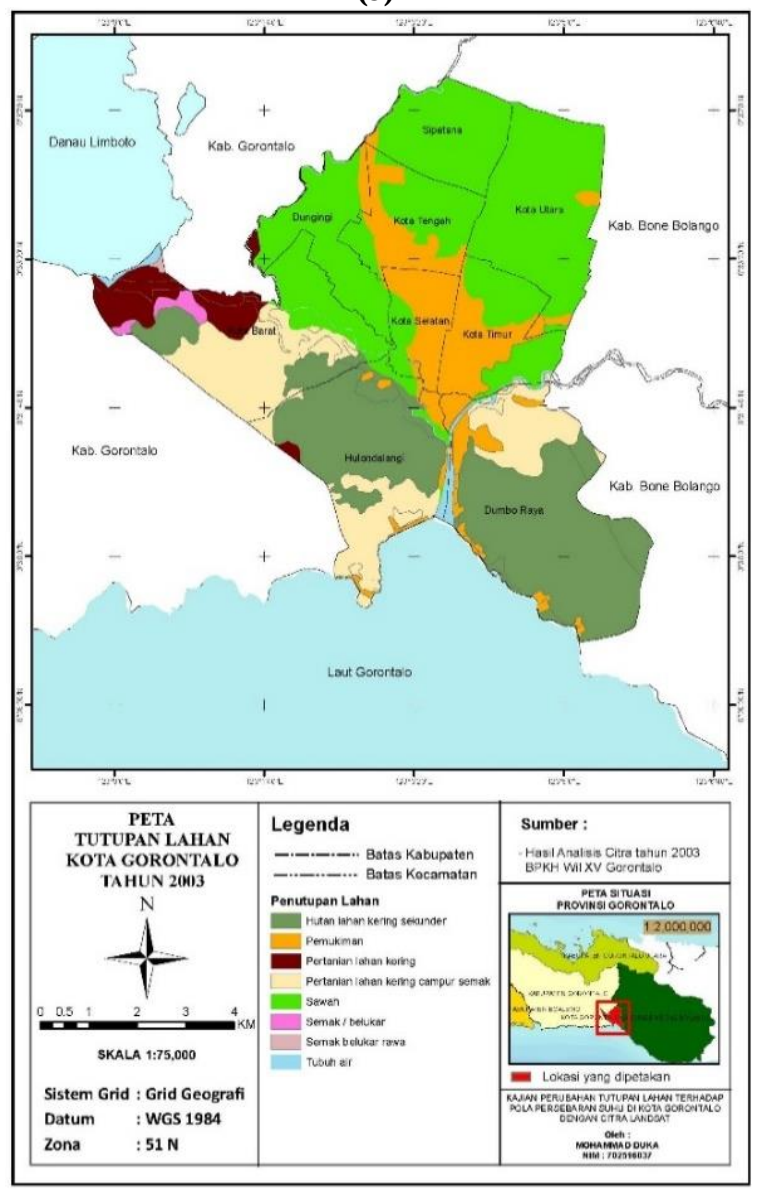

Gambar 2. Peta tutupan lahan di Kota Gorontalo, (a) Tahun 1990; (b) Tahun 2003; (c) Tahun 2017 
Tabe1 3. Luas wilayah berdasarkan suhu menurut kecamatan di Kota Gorontalo tahun 1990 Luas kecamatan $(\mathrm{Ha})$

\begin{tabular}{|c|c|c|c|c|c|c|c|c|c|}
\hline \multirow[b]{2}{*}{ Kelas suhu } & \\
\hline & 总 & 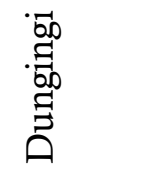 & 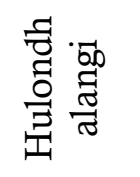 & 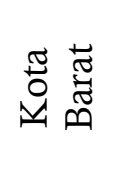 & 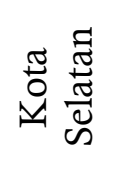 & 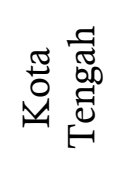 & 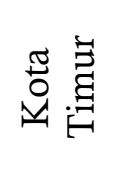 & 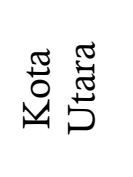 & 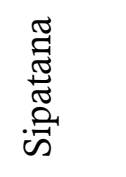 \\
\hline$<8$ & 7.18 & & & & & & & & \\
\hline $8-8.9$ & 31.66 & & & & & & & & \\
\hline $9-9.9$ & 25.43 & & & & & & & & \\
\hline $10-10.9$ & 27.31 & & & 10.15 & & & & & \\
\hline $11-11.9$ & 28.97 & & 1.98 & 172.54 & & & & & \\
\hline $12-12.9$ & 41.80 & 0.63 & 20.33 & 205.49 & & 2.66 & & 1.80 & 1.27 \\
\hline $13-13.9$ & 69.14 & 33.48 & 123.59 & 194.30 & & 58.20 & & 119.30 & 88.04 \\
\hline $14-14.9$ & 80.37 & 95.80 & 82.67 & 129.97 & & 72.46 & 0.12 & 144.36 & 54.19 \\
\hline $15-15.9$ & 347.29 & 262.03 & 226.65 & 232.84 & 9.71 & 191.31 & 78.67 & 326.89 & 176.86 \\
\hline $16-16.9$ & 313.13 & 57.96 & 227.65 & 107.60 & 28.43 & 97.89 & 49.10 & 127.77 & 121.95 \\
\hline $17-17.9$ & 260.40 & 13.09 & 184.20 & 68.95 & 55.64 & 38.41 & 73.44 & 29.96 & 23.36 \\
\hline $18-18.9$ & 160.42 & 1.63 & 134.57 & 25.36 & 63.98 & 19.52 & 147.20 & 20.68 & 1.66 \\
\hline $19-19.9$ & 38.84 & & 48.49 & 14.96 & 65.99 & 3.32 & 120.55 & 33.24 & \\
\hline $20>$ & 1.23 & & 3.57 & 2.42 & 58.03 & & 43.91 & 33.83 & \\
\hline
\end{tabular}

Sumber : hasil interpretasi Citra Landsat tahun 1990

pemukiman, pusat pemerintahan, area perdagangan dan jasa, kawasan industri dan jalan raya. Tingginya pertumbuhan jumlah penduduk perkotaan di Indonesia, memberikan konsekuensi meningkatnya permintaan sarana dan prasarana kota (Iriyanto, 2008). Perkembangan cepat suatu kota dipastikan menyebabkan terjadinya perubahan pemanfaatan ruang. Hal ini dikarenakan tanah merupakan sumber daya yang terbatas. Dengan demikian, cepat atau lambat, dengan meningkatnya laju pertumbuhan penduduk dan urbanisasi, berbagai penggunaan lahan di perkotaan akan mulai saling bertentangan.

Selanjutnya pada kawasan sawah mengalami perubahan luas dari periode tahun 1990 sampai dengan tahun 2017. Luas persawahan di Kota Gorontalo mengalami penurunan luas sebesar $1290.15 \mathrm{Ha}$. Hal ini merupakan imbas dari peningkatan jumlah penduduk, aktivitas dan proses pembangunan. Konversi lahan merupakan konsekuensi logis dari peningkatan aktivitas dan jumlah penduduk serta proses pembangunan lainnya. Konversi lahan pada tahap tertentu wajar terjadi, namun pada sisi lain jika tidak dikendalikan maka akan semakin bermasalah karena umumnya alih fungsi terjadi di atas lahan pertanian yang masih produktif (Arsyad \& Rustiyati, 2008; Budi, 2015).

\subsection{Distribusi Suhu Permukaan di Kota Gorontalo}

\subsubsection{Distribusi suhu permukaan tahun 1990}

Pada Tahun 1990, distribusi suhu permukaan di Kota Gorontalo tertinggi yaitu pada kelas suhu 15$15.9{ }^{\circ} \mathrm{C}$ dengan luas $1852.25 \mathrm{Ha}$. Kondisi tersebut tersebar di wilayah Kecamatan Dumbo Raya, Dungingi, Hulondhalangi, Kota Barat, Kota Timur, Kota Selatan, Kota Utara, Kota Tengah dan Kecamatan Sipatana. Berdasarkan hasil layout antara peta administratif Kota Gorontalo dan peta distribusi suhu permukaan pada Tahun 1990 terlihat bahwa suhu permukaan yang relatif rendah (suhu permukaan $<8^{\circ} \mathrm{C}$ ) yang tersebar di Kecamatan Dumbo Raya. Sedangkan suhu permukaan yang relatif tinggi (suhu permukaan $>20^{\circ} \mathrm{C}$ ) tersebar pada wilayah Kecamatan Dumbo Raya, Hulondhalangi, Kota Barat, Kota Selatan, Kota Timur dan Kota Utara. Hasil interpretasi terhadap citra landsat diperoleh persebaran suhu di Kota Gorontalo seperti ditunjukkan pada Tabel 3. Peta sebaran suhu permukaan di Kota Gorontalo ditunjukkan pada Gambar 3.

\subsubsection{Distribusi suhu permukaan tahun 2003}

Tahun 2003 distribusi suhu permukaanyang relatif rendah adalah suhu permukaan $<12{ }^{\circ} \mathrm{C}$ yang tersebar di Kecamatan Dumbo Raya, Kecamatan Dungingi, dan Kecamatan Kota Barat. Suhu permukaan yang relatif tinggi (suhu permukaan $>21^{\circ} \mathrm{C}$ ) tersebar pada wilayah Kecamatan Dumbo Raya, Hulondhalangi, Kota Barat, Kota Selatan, Kota Timur, dan Kota Utara (Tabel 4). Distribusi suhu permukaan di wilayah kecamatan yang terdapat di Kota Gorontalo tertinggi yaitu pada kelas suhu 14$14.9^{\circ} \mathrm{C}$ dengan luas 1912.29 Ha yang tersebar di wilayah Kecamatan Dumbo Raya, Dungingi, 


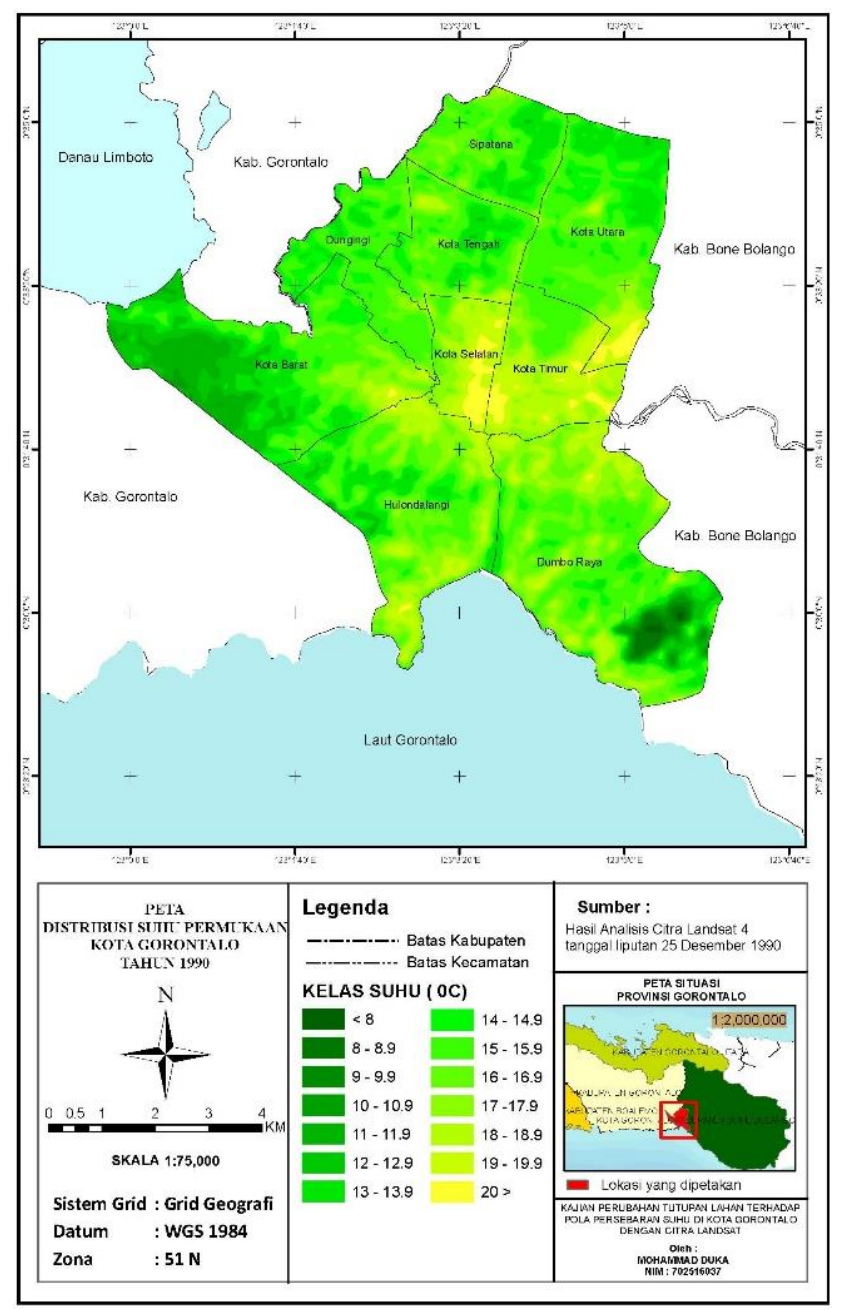

Gambar 3. Peta distribusi suhu berdasarkan kecamatan di Kota Gorontalo Tahun 1990

Hulondhalangi, Kota Barat, Kota Timur, Kota Selatan, Kota Utara, Kota Tengah dan Kecamatan Sipatana. Berdasarkan wilayah administrasi, distribusi kelas suhu tertinggi yaitu terdapat di wilayah Kecamatan Kota Barat dengan luas distribusi suhu permukan sebesar $1164.80 \mathrm{Ha}$, sedangkan wilayah

Tabel 4. Luas wilayah berdasarkan suhu menurut kecamatan di Kota Gorontalo tahun 2003

\begin{tabular}{|c|c|c|c|c|c|c|c|c|c|}
\hline \multirow[b]{2}{*}{ Kelas suhu } & \multicolumn{9}{|c|}{ Luas kecamatan $(\mathrm{Ha})$} \\
\hline & 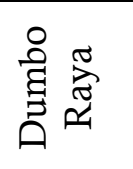 & 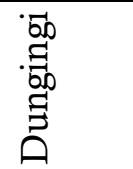 & 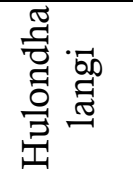 & 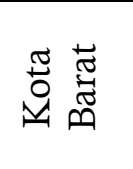 & 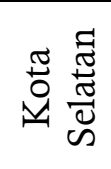 & 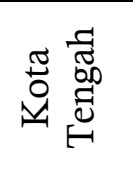 & 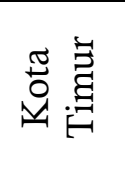 & 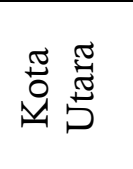 & 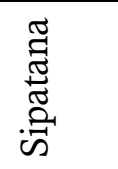 \\
\hline$<8$ & 7.18 & & & & & & & & \\
\hline $8-8.9$ & 31.66 & & & & & & & & \\
\hline $9-9.9$ & 25.43 & & & & & & & & \\
\hline $10-10.9$ & 27.31 & & & 10.15 & & & & & \\
\hline $11-11.9$ & 28.97 & & 1.98 & 172.54 & & & & & \\
\hline $12-12.9$ & 41.80 & 0.63 & 20.33 & 205.49 & & 2.66 & & 1.80 & 1.27 \\
\hline $13-13.9$ & 69.14 & 33.48 & 123.59 & 194.30 & & 58.20 & & 119.30 & 88.04 \\
\hline $14-14.9$ & 80.37 & 95.80 & 82.67 & 129.97 & & 72.46 & 0.12 & 144.36 & 54.19 \\
\hline $15-15.9$ & 347.29 & 262.03 & 226.65 & 232.84 & 9.71 & 191.31 & 78.67 & 326.89 & 176.86 \\
\hline $16-16.9$ & 313.13 & 57.96 & 227.65 & 107.60 & 28.43 & 97.89 & 49.10 & 127.77 & 121.95 \\
\hline $17-17.9$ & 260.40 & 13.09 & 184.20 & 68.95 & 55.64 & 38.41 & 73.44 & 29.96 & 23.36 \\
\hline $18-18.9$ & 160.42 & 1.63 & 134.57 & 25.36 & 63.98 & 19.52 & 147.20 & 20.68 & 1.66 \\
\hline $19-19.9$ & 38.84 & & 48.49 & 14.96 & 65.99 & 3.32 & 120.55 & 33.24 & \\
\hline $20>$ & 1.23 & & 3.57 & 2.42 & 58.03 & & 43.91 & 33.83 & \\
\hline
\end{tabular}




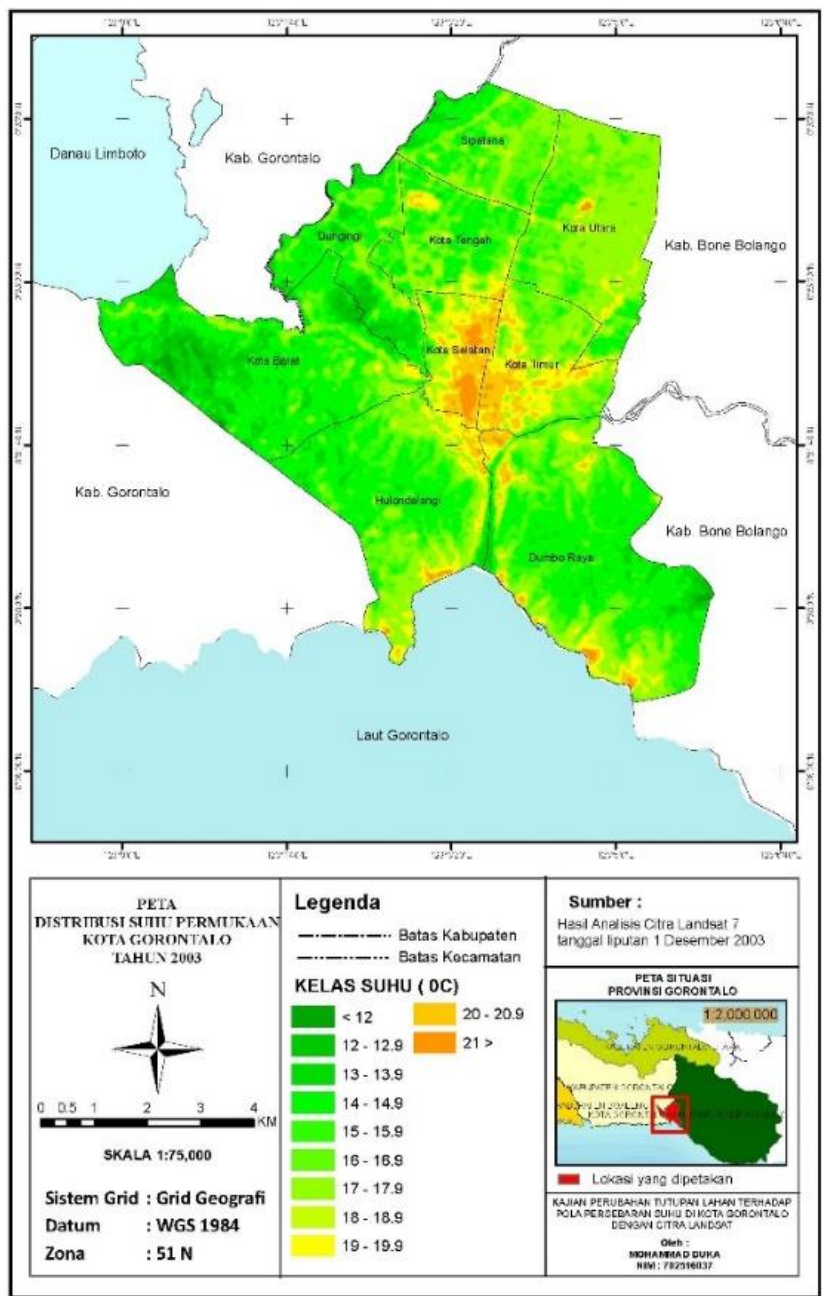

Gambar 4. Peta distribusi suhu berdasarkan kecamatan di Kota Gorontalo tahun 2003

dengan luas distribusi suhu permukaan rendah adalah Kecamatan Kota Tengah dengan luas sebesar 281.77 Ha (Gambar 4).

\subsubsection{Distribusi suhu permukaan tahun 2017}

Tahun 2017 suhu permukaan yang relatif rendah adalah suhu permukaan $<12{ }^{\circ} \mathrm{C}$ yang tersebar di Kecamatan Dumbo Raya, Kecamatan Dungingi dan Kecamatan Kota Barat. Suhu permukaan yang relatif tinggi (suhu permukaan $>21^{\circ} \mathrm{C}$ ) tersebar pada wilayah Kecamatan Dumbo Raya, Hulondhalangi, Kota Barat, Kota Selatan, Kota Timur dan Kota Utara. Distribusi suhu permukaan di Kota Gorontalo tertinggi yaitu pada kelas suhu $14-14.9^{\circ} \mathrm{C}$ dengan luas $1912.29 \mathrm{Ha}$ yang tersebar di wilayah Kecamatan Dumbo Raya, Dungingi, Hulondhalangi, Kota Barat, Kota Timur, Kota Selatan, Kota Utara, Kota Tengah dan Kecamatan Sipatana (Tabel 5). Berdasarkan wilayah administrasi, distribusi kelas suhu tertinggi terdapat di wilayah Kecamatan Kota Barat dengan luas distribusi suhu permukan sebesar $1164.80 \mathrm{Ha}$.Wilayah Kota Gorontalo dengan luas distribusi suhu permukaan rendah adalah Kecamatan Kota Tengah dengan luas sebesar 281.77 Ha (Gambar 5).

Hasil Citra Landsat tahun 1990 dan 2003 suhu permukaan di Kota Gorontalo berkisar antara $<12^{\circ} \mathrm{C}$ $->21{ }^{\circ} \mathrm{C}$, sedangkan pada periode tahun 2017 hasil citra landsat suhu permukaan di Kota Gorontalo berkisar antara $<21^{\circ} \mathrm{C}-34>^{\circ} \mathrm{C}$ (Gambar 6).

\subsection{Rata-Rata Suhu Permukaan Tiap Tipe Tutupan Lahan}

Rata-rata suhu permukaan terendah terdapat pada kelas tutupan semak belukar, rawa dan hutan lahan kering sekunder. Suhu permukaan yang tertinggi terdapat pada kelas tutupan lahan pertambangan dan pemukiman. Perbandingan antara suhu permukaan pada lahan pemukiman dan pertambangan dengan tutupan lahan lainnya menunjukkan selisih yang besar (Tabel 6). Hal ini disebabkan energi yang terpancar dan terekam oleh sensor satelit pada lahan pemukiman dan pertambangan lebih besar dibandingkan tutupan lahan lainnya. Pada hutan lahan kering sekunder terjadi penurunan suhu pada Tahun 2017 dibanding suhu pada Tahun 2003 (Tabel 6). Hal ini disebabkan pada tutupan lahan hutan, 
Tabel 5. Luas wilayah berdasarkan suhu menurut kecamatan di Kota Gorontalo tahun 2017 Luas kecamatan $(\mathrm{Ha})$

\begin{tabular}{|c|c|c|c|c|c|c|c|c|c|}
\hline Kelas suhu & 茵 & 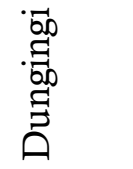 & 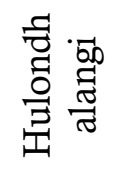 & 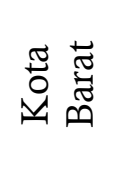 & $\begin{array}{l}\mathbb{\Xi} \\
\stackrel{\mathbb{\Xi}}{0} \\
\stackrel{\mathbb{\Xi}}{\mathbb{D}}\end{array}$ & 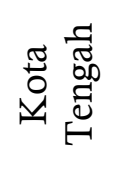 & 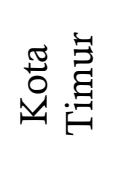 & 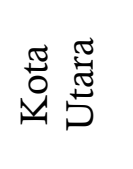 & 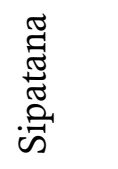 \\
\hline$<12$ & 3,86 & 1,25 & & 23,49 & & & & & \\
\hline $12-12,9$ & 17,51 & 28,90 & 1,11 & 95,19 & & 0,09 & & & 2,29 \\
\hline $13-13,9$ & 76,86 & 81,84 & 41,71 & 244,52 & 0,12 & 6,75 & 0,02 & 0,06 & 21,70 \\
\hline $14-14,9$ & 555,24 & 177,83 & 338,39 & 512,74 & 6,68 & 140,17 & 9,02 & 60,04 & 112,17 \\
\hline $15-15,9$ & 240,40 & 65,69 & 177,31 & 129,92 & 7,83 & 107,74 & 39,06 & 103,69 & 109,63 \\
\hline $16-16,9$ & 168,54 & 56,67 & 142,60 & 70,83 & 11,90 & 77,78 & 83,52 & 177,76 & 114,40 \\
\hline $17-17,9$ & 200,66 & 44,53 & 193,57 & 68,85 & 41,37 & 90,41 & 134,68 & 415,05 & 104,74 \\
\hline $18-18,9$ & 52,45 & 5,11 & 54,54 & 10,96 & 23,23 & 21,44 & 46,97 & 46,99 & 13,00 \\
\hline $19-19,9$ & 64,31 & 1,82 & 72,02 & 7,24 & 68,69 & 31,05 & 110,35 & 27,27 & 2,52 \\
\hline $20-20,9$ & 37,01 & 0,00 & 25,33 & 0,78 & 82,75 & 7,34 & 81,83 & 4,68 & \\
\hline $21>$ & 8,25 & & 3,96 & 0,27 & 39,20 & & 7,47 & 2,23 & \\
\hline
\end{tabular}

Sumber : hasil interpretasi Citra Landsat tahun 2017

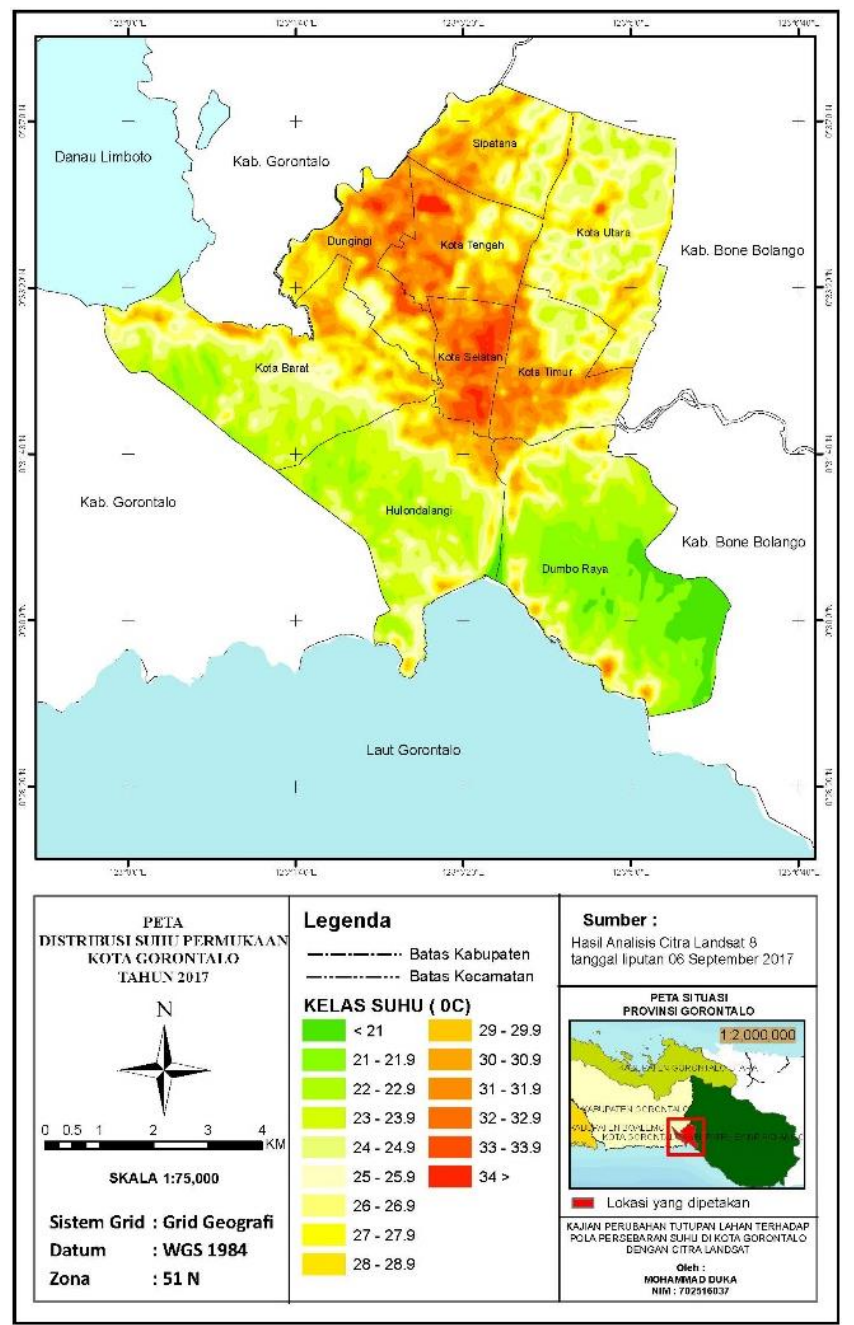

Gambar 5. Peta distribusi suhu berdasarkan kecamatan di Kota Gorontalo tahun 2017

kerapatan vegetasi lebih tinggi. Hal ini akan berpengaruh pada kondisi evapotranspirasi. Evapotranspirasi dapat mendinginkan udara disekitarnya karena terdapat penyerapan panas saat terjadi evaporasi (Block et al., 2012). Pada pertanian lahan kering dan semak belukar kondisi kerapatan vegetasi lebih rendah dibanding hutan. Hal ini mengakibatkan suhu menjadi lebih tinggi. Pada tubuh air, suhu permukaan lebih rendah. Hal ini disebabkan karena air merupakan sumber kelembaban. 


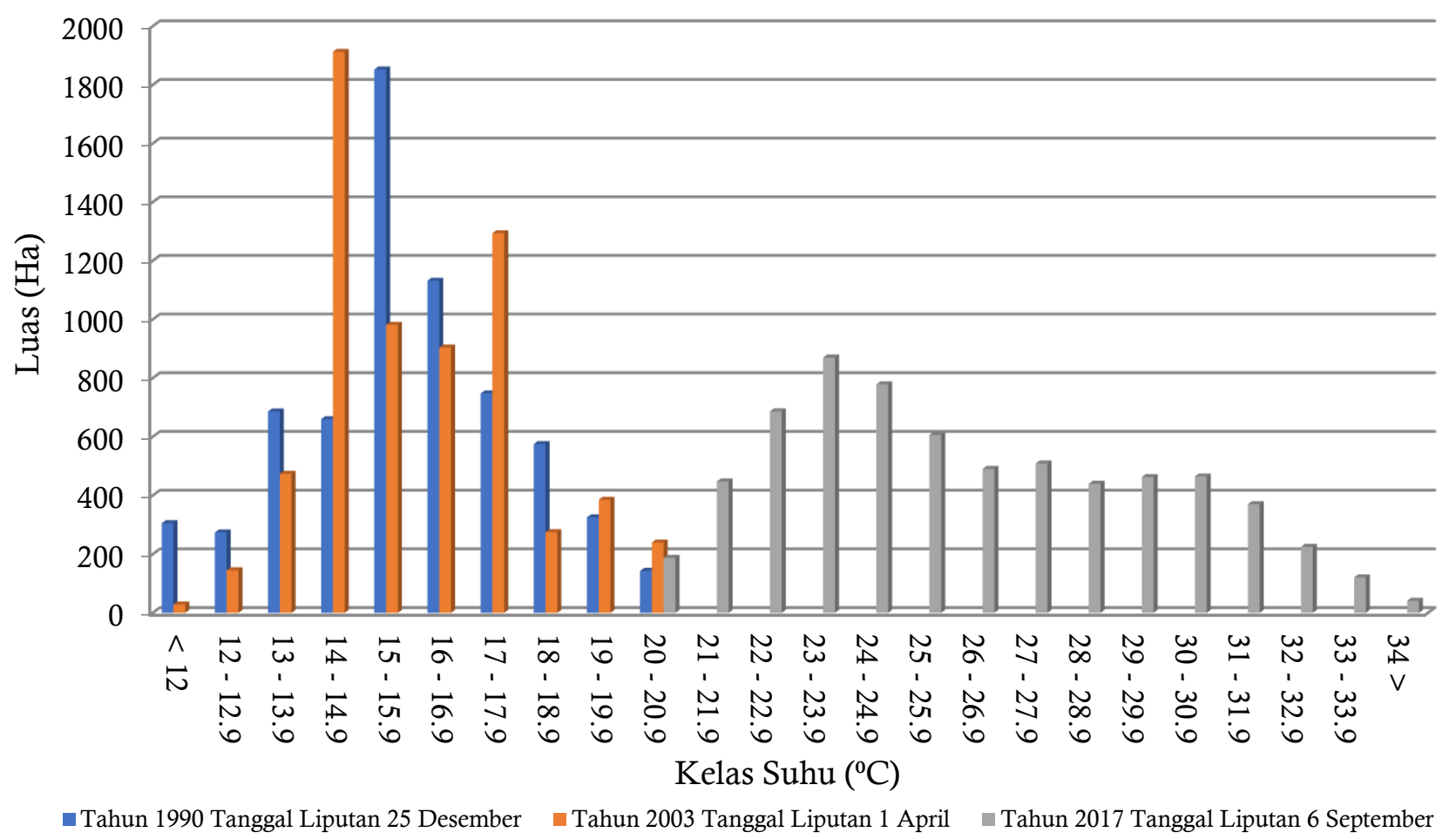

Gambar 6. Distribusi suhu permukaan di Kota Gorontalo periode tahun 1990, 2003, dan 2017

Tabel 6. Rata-rata suhu permukaan berdasarakan tutupan lahan pada tahun 1990, 2003, dan 2017

\begin{tabular}{lllll}
\hline \multirow{2}{*}{ No } & \multirow{2}{*}{ Jenis tutupan } & \multicolumn{3}{l}{ Suhu rata-rata $\left({ }^{\circ} \mathrm{C}\right)$} \\
\cline { 3 - 4 } & & Tahun 1990 & Tahun 2003 & Tahun 2017 \\
\hline 1 & Hutan lahan kering sekunder & 18,02 & 27,12 & 23,69 \\
2 & Pemukiman & 23,5 & 27,46 & 28,42 \\
3 & Pertanian lahan kering & 21,63 & 20,76 & 27,2 \\
4 & Pertanian lahan kering campur semak & 25,6 & 27,64 & 27,04 \\
5 & Sawah & 26,63 & 27,27 & 27,74 \\
6 & Semak / belukar & 26,38 & 23,47 & 27,36 \\
7 & Semak belukar rawa & 17,5 & 19,08 & 26,64 \\
8 & Tubuh Air & 21,53 & 22,63 & 18,86 \\
9 & Pertambangan & & & 28,87 \\
\hline
\end{tabular}

Sumber : hasil interpretasi Citra Landsat, 1990, 2003, dan 2017

\subsection{Hubungan Antara Tipe Penutupan Lahan dan Perubahan Suhu Permukaan}

Kerapatan vegetasi dapat dijelaskan melalui Nilai Indeks Vegetasi (NDVI). Nilai NDVI yang dihasilkan dari data citra Landsat dapat menggambarkan kerapatan vegetasi suatu wilayah (Sobrino et al., 2004). Nilai NDVI hasil ekstraksi data citra Landsat dapat merepresentasikan distribusi vegetasi dan memetakannya berdasarkan pola karakteristik reflektansi klorof serta perbedaan jumlah vegetasi (Affan, 2002). Menurut Sobrino et al., (2004) reflektansi radiasi matahari dalam bentuk gelombang elektromagnetik yang mengenai pepohonan dipengaruhi oleh karakteristik tajuk yang berupa kerapatan tajuk, ketebalan tajuk dan persentase kerapatan kanopinya.

Hasil analisis dengan menggunakan koefisien korelasi antara suhu permukaan dan nilai NDVI menunjukkan adanya hubungan negatif antara suhu permukaan dan indeks vegetasi. Hasil perhitungan menghasilkan nilai koefisien korelasi sebesar $r=-0.141$ untuk Tahun 1990, $r=-0.448$ untuk Tahun 2003 dan $r=-0.402$ untuk Tahun 2017. Tanda negatif menunjukkan suatu hubungan dengan arah yang berlawanan atau setiap kenaikan nilai indeks vegetasi terjadi penurunan nilai suhu permukaan. Besarnya penurunan suhu permukaan tersebut secara sederhana dinyatakan dalam persamaan regresi linier yaitu:

1. Tahun $1990:$ Suhu $=15.82-2.01$ NDVI $\left(\mathrm{R}^{2}=0,019\right)$

2. Tahun $2003:$ Suhu $=24.982-3.793$ NDVI $\left(\mathrm{R}^{2}=0,020\right)$

3. Tahun $2017:$ Suhu $=28.002-8.579$ NDVI $\left(R^{2}=0,161\right)$ 
Berdasarkan hasil uji korelasi antara NDVI dan suhu permukaan terlihat hubungan korelasi negatif hanya berada pada nilai-nilai NDVI diatas nol, pada nilai NDVI dibawah nol (angka negatif) suhu cenderung menurun. Hal ini dikarenakan nilai NDVI dibawah nol sampai dengan -1 umumnya menunjukan tutupan badan air yang umumnya juga memiliki suhu permukaan yang relatif rendah. Nilai NDVI yang mendekati 0 pada umumnya merupakan tutupan lahan terbangun atau lahan terbuka yang memiliki suhu permukaan yang lebih tinggi. Nilai $\mathrm{R}^{2}$ merupakan nilai koefisien determinasi yang menyatakan besarnya persentase nilai suhu permukaan yang dapat dijelaskan oleh nilai NDVI dan sisanya dijelaskan oleh faktor lain yang tidak terdapat pada model.

Nilai koefisien determinasi yang terus mengalami penurunan dari data Tahun 1990, 2003 dan 2017 dapat menunjukan peran vegetasi yang semakin menurun terhadap besarnya suhu permukaan. Pada Tahun 1990 nilai koefisien determinasi adalah 0,019. Pada Tahun 2003, nilai koefisien determinasi sebesar 0,020. Pada Tahun 2017 nilai koefieisn determinasi sebesar 0,16. Dengan demikian kontribusi vegetasi terhadap perubahan suhu di Kota Gorontalo sebesar 1,9\% (Tahun 1990), 2\% (Tahun 2003) dan meningkat menjadi 16\% (Tahun 2017). Salah satu hal yang mempengaruhi penurunan peran vegetasi terhadap besarnya suhu permukaan adalah adanya perubahan tutupan lahan. Sebagaimana hasil analisis tutupan lahan dari data Tahun 1990, 2003 dan 2017 menunjukan adanya perubahan tutupan lahan yang semula berupa hutan, kebun campuran, dan semak menjadi lahan-lahan pertanian serta perubahan lahan-lahan bervegetasi menjadi lahan terbangun (Gambar 2).

Hasil analisis antara data distribusi suhu permukaan dan tutupan lahan pada Tahun 1990, 2003 dan 2017 secara umum menunjukkan adanya perbedaan nilai suhu permukaan pada setiap tutupan lahan serta menunjukan adanya peningkatan suhu pada ketiga tahun tersebut. Tutupan lahan mempengaruhi reflektivitas radiasi matahari yang jatuh ke suatu tempat dan pada akhirnya radiasi matahari reflektif menjadi penyebab naik turunnya temperatur suatu tempat (Sugini, 2014). Setiap tutupan lahan memiliki tingkat kemampuan yang berbeda untuk merefleksikan kembali panas ke langit. Adanya perbedaan suhu permukaan pada beberapa tutupan lahan disebabkan oleh perbedaan sifat fisik setiap permukaan benda yaitu kapasitas panas jenis dan konduktivitas termalnya (Adiningsih et al., 2001). Setiap permukaan menerima energi radiasi matahari yang sama tetapi dengan kapasitas panas yang berbeda maka suhu yang dihasilkan juga berbeda. Jika suatu benda berkapasitas panas besar maka suhu yang dihasilkan rendah, sedangkan benda yang berkapasitas panas kecil menghasilkan suhu yang tinggi. Kapasitas panas dipengaruhi oleh kapasitas panas jenis dan massa jenis atau kerapatan suatu benda. Kecepatan benda menjadi panas tergantung dari konduktivitas termalnya, semakin besar konduktivitas termal maka suatu benda semakin cepat merambatkan panas sehingga suhu semakin cepat meningkat, sebaliknya jika suatu benda memiliki konduktivitas termal yang kecil maka benda tersebut semakin lambat merambatkan panas sehingga suhu lebih lambat untuk meningkat (Adiningsih et al., 2001).

Tutupan lahan mempengaruhi reflektivitas radiasi matahari yang jatuh ke suatu tempat dan pada akhirnya radiasi matahari reflektif menjadi penyebab naik turunnya temperatur suatu tempat (Sugini, 2014). Setiap tutupan lahan memiliki tingkat kemampuan yang berbeda untuk merefleksikan kembali panas ke langit. Adanya perbedaan suhu permukaan pada beberapa tutupan lahan disebabkan oleh perbedaan sifat fisik setiap permukaan benda yaitu kapasitas panas jenis dan konduktivitas termalnya (Adiningsih et al., 2001). Setiap permukaan menerima energi radiasi matahari yang sama tetapi dengan kapasitas panas yang berbeda maka suhu yang dihasilkan juga berbeda. Jika suatu benda berkapasitas panas besar maka suhu yang dihasilkan rendah, sedangkan benda yang berkapasitas panas kecil menghasilkan suhu yang tinggi. Kapasitas panas dipengaruhi oleh kapasitas panas jenis dan massa jenis atau kerapatan suatu benda. Kecepatan benda menjadi panas tergantung dari konduktivitas termalnya, semakin besar konduktivitas termal maka suatu benda semakin cepat merambatkan panas sehingga suhu semakin cepat meningkat, sebaliknya jika suatu benda memiliki konduktivitas termal yang kecil maka benda tersebut semakin lambat merambatkan panas sehingga suhu lebih lambat untuk meningkat.

Vegetasi menyerap panas dari pancaran sinar matahari untuk melakukan metabolisme dalam dirinya sehingga dapat menurunkan suhu. Fotosintesis yang merupakan proses pada tumbuhan ditentukan oleh energi yang bersumber dari sinar matahari. Fotosintesis mengikat energi surya menjadi energi dalam bentuk bahan kimia kaya energi yang dapat menjadi sumber makanan makhluk hidup. Proses fotosintesis secara simultan terjadi dengan proses transpirasi pada tumbuhan yang juga dapat menurunkan suhu. Saat transpirasi, terjadi penguapan air melalui pori-pori daun dan cabang tanaman. Besarnya transpirasi dalam batas tertentu dipengaruhi oleh karakteristik dan kerapatan vegetasi seperti struktur tajuk, perilaku pori-pori daun dan sebagainya (Asdak, 2014)

Hasil analisis hubungan suhu permukaan dan tutupan lahan menunjukkan lahan bervegetasi terutama hutan memiliki suhu yang relatif lebih rendah jika dibandingkan lahan terbangun. Kemampuan vegetasi 
dalam menyerap radiasi matahari lebih baik jika dibandingkan dengan lahan terbangun. Struktur vegetasi juga berpengaruh terhadap kemampuan vegetasi dalam menyerap radiasi matahari. Jenis vegetasi tertentu dengan struktur yang rapat seperti pohon yang memiliki lapisan tajuk dengan banyak daun, ranting dan cabang menawarkan manfaat yang lebih besar karena dapat mengurangi radiasi yang ditransmisikan secara terus menerus (Armson, 2012). Pohon juga menawarkan efek peneduhan dari fungsi pembayangan. Purnomohadi (1995) dan Wonohardjo (2010) juga menyimpulkan bahwa vegetasi pohon berpengaruh positif terhadap fungsi ameliorasi suhu, baik melalui evapotranspirasi, refleksi matahari yang tinggi serta efek pembayangan permukaan di bawah kanopi. Penanaman sekelompok pepohonan yang berkerapatan tinggi merupakan perlindungan dalam mengurangi temperatur yang tinggi pada siang hari (Fandely \& Muhamad, 2009).

Kekurangan dari penelitian ini adalah belum dilakukannya validasi hasil interpretasi suhu di Kota Gorontalo dengan kondisi suhu aktual. Keterbatan stasiun iklim menyebabkan data suhu aktual di Kota Gorontalo tidak tersedia.

\section{Kesimpulan}

Trend perubahan suhu permukaan yang terjadi di Kota Gorontalo yaitu suhu permukaan di Kota Gorontalo periode Tahun 1990, 2003 dan 2017 mengalami peningkatan. Peningkatan suhu permukaan terjadi pada tutupan vegetasi yang telah mengalami perubahan luas. Kelas suhu permukaan rendah mengalami penurunan luas dari tiga tahun peliputan dan mengalami peningkatan perubahan luas penutupan pada lahan dengan kelas suhu permukaan tinggi, dengan pola distribusi suhu permukaan yang berbeda pada masing-masing wilayah yang berada di Kota Gorontalo.

Hubungan antara suhu permukaan dan tutupan lahan menunjukkan bahwa vegetasi hutan memiliki suhu permukaan yang lebih rendah jika dibandingkan dengan lahan terbangun, serta suhu permukaan pada setiap vegetasi berbeda bergantung pada karakteristik vegetasi yang ditunjukkan oleh hubungan nilai indeks vegetasi dan suhu permukaan yang menunjukan korelasi negatif dengan nilai berturut-turut pada Tahun 1990, 2003 dan 2017 sebesar -0.141, -0.448 dan -0.402. Perubahan suhu permukaan di Kota Gorontalo dipengaruhi oleh adanya perubahan tutupan lahan yang ditandai oleh kesamaan pola perubahan distribusi suhu permukaan dengan pola perubahan tutupan lahan.

\section{Referensi}

Adiningsih, E. S., Soenarmo, S. H., \& Mujiasih. (2001). Kajian Perubahan Distribusi Spasial Suhu Udara Akibat Perubahan Penutup Lahan. Studi Kasus Cekungan Bandung. Jurnal Lapan.

Affan, M. J. (2002). Penilaian Tingkat Bahaya Kebakaran Hutan Berdasarkan Indeks Vegetasi dan KDBI. Bogor: Jurusan Geofisika dan Meteorologi, FMIPA IPB.

Asdak, C. (2014). Hidrologi dan Pengelolaan Daerah Aliran Sungai. Yogyakarta: Gadjah Mada University Press.

Block, A. H., Livesley, S., \& William, N. (2012). Responding to the Urban Heat Island: A Review of the Potential Green Infrastructure. Victorian Centre for Climate Change Adaptation Research. Victorian Centre for Climate Change Adaptation Research.

Fandely, C., \& Muhamad. (2009). Prinsip-prinsip Dasar Mengkonservasi. Yogyakarta: Gadjah Mada University Press.

Iriyanto, S. (2008). Analisis Kebijakan Program Pembangunan Prasarana Kota Terpadu (P3KT) Kota Liwa Kabupaten Lampung Barat dan Arah Kebijakan Pembangunan Kota Liwa Pada Era Otonomi Daerah (Studi Kasus P3KT: Komponen Air Bersih). Jakarta: Perpustakaan Universitas Indonesia.

Jaya, I. (2010). Analisis Citra Digital: Perspektif Penginderaan Jauh untuk Pengelolaan Sumberdaya Alam. Bogor: Departemen Manajemen Hutan; Fakultas Kehutanan IPB.

Kong, F., Yin, H., James, P., Hutyra, L., \& He, H. S. (2014). Effects of Spatial pattern of greenspace on urban cooling in large metropolitan area of eastern China. Landscape and Urban Planning, 35 - 47.

Lillesand, T. M., \& Kiefer, R. W. (2000). Remote Sensing and Image Interpretation. (IV ed.). New York: Wiley \& Sons.

Nurhayati. (2016). Analisis Fenomena Pulau Panas (Heat Island) Di Kabupaten Majalengka. Tesis. Program Studi Magister Ilmu Lingkungan. Universitas Padjajaran. Bandung. Bandung: Program Studi Magister Ilmu Lingkungan Universitas Padjajaran.

Purnomohadi, S. (1995). Peran Ruang Terbuka Hijau dalam Pengendalian Kualitas Udara di DKI Jakarta. Bogor: IPB Bogor.

Sugini. (2014). Kenyamanan Termal Ruang; Konsep dan Penerapan pada Desain. Yogyakarta: Graha Ilmu. 
Tatura, L. S. (2010). Kajian perubahan tutupan lahan dalam Rencana Tata Ruang Wilayah Kota Gorontalo. Jurnal Inovasi, Vo. 10(1). Diambil kembali dari http://ejurnal.ung.ac.id

US Environmental Protection Agency. (2012, September). Guideline for water reuse. Washington DC. Diambil kembali dari https://www.epa.gov

Wonohardjo, S. (2010). Pengaruh Karakteristik Fisik Terhadap Fenomena Pulau Panas (Heat Island) Kawasan Kota Bandung. . Bandung: Program Studi Arsitektur Institut Teknologi Bandung. 